\title{
Fungi on decaying leaves of Magnolia liliifera and Cinnamomum iners show litter fungi to be hyperdiverse
}

\section{Monkai $\mathbf{J}^{1,2^{*}}$, Promputtha $\mathbf{I}^{3}$, Kodsueb $\mathbf{R}^{4}$, Chukeatirote $\mathbf{E}^{1,2}$, McKenzie EHC $^{5}$ and Hyde $\mathrm{KD}^{1,2}$}

\footnotetext{
${ }^{1}$ School of Science, Mae Fah Luang University, Thasud, Chiang Rai 57100, Thailand

${ }^{2}$ Institute of Excellence in Fungal Research, Mae Fah Luang University, 57100 Chiang Rai, Thailand

${ }^{3}$ School of Cosmetic Science, Mae Fah Luang University, Thasud, Chiang Rai 57100, Thailand

${ }^{4}$ Faculty of Science and Technology, Pibulsongkram Rajabhat University, Phitsanulok 65000, Thailand

${ }^{5}$ Landcare Research, Private Bag 92170, Auckland, New Zealand
}

Monkai J, Promputtha I, Kodsueb R, Chukeatirote E, McKenzie EHC, Hyde KD 2013 - Fungi on decaying leaves of Magnolia liliifera and Cinnamomum iners show litter fungi to be hyperdiverse. Mycosphere 4(2), 292-301, Doi 10.5943/mycosphere/4/2/12

Diversity of fungi on decaying leaves of Magnolia liliifera and Cinnamomum iners collected during the dry season at Doi Suthep-Pui forest, Chiang Mai, Thailand were studied and compared. Thirtyfive taxa were identified from Magnolia liliifera comprising 8 sexual (ascomycetes) and 27 asexual taxa. The most abundant species found were Sporidesmium sp., Colletotrichum fructicola and Stachybotrys parvispora. Seventeen taxa were identified from Cinnamomum iners comprising 2 ascomycetes and 15 asexual taxa. Anamorph of Eutypa sp. 2 and Pleurophragmium sp. were the most abundant species on Cinnamomum iners. There is very little overlap between the fungi occurring on the two host species. Distinct fungal communities were found between the two hosts at each stage of decomposition. Decaying leaves of both hosts collected in the early stage of decomposition supported a greater fungal diversity than those collected at the later stage of decomposition. Saprobic fungi on the two plants are shown to be hyperdiverse.

Key words - biodiversity estimates - fungal ecology - saprobic fungi

\section{Article Information}

Received 11 March 2013

Accepted 14 April 2013

Published online 20 April 2013

*Corresponding author: Jutamart Monkai - e-mail - mjutamart@ gmail.com

\section{Introduction}

Saprobic fungi function as decomposers of organic materials and recycle nutrients to other organisms (Cooke \& Rayner 1984). The number of fungi worldwide was estimated at 1.5 million species by Hawksworth (1991, 2001b). However, only 70,000 species are presently described leaving the remaining 1.43 million (or 95\%) as being undescribed. It is therefore important to search for these undescribed fungi which occur in unexplored habitats, hosts or poorly studied countries especially in tropical regions (Hawksworth \& Rossman 1997). Forests of the northern part of Thailand have great plant diversity (Gardner et al. 2000) and several studies on their fungal diversity have been carried out in recent years (Duong et al. 2008, Thongkantha et al. 2008, 
Wang et al. 2008, Osono et al. 2009, Bhilabutra et al. 2010, Sysouphanthong et al. 2010, Zhao et al. 2010, Vasilyeva et al. 2012). This has resulted in taxonomic advances (see Fournier et al. 2010, Boonmee et al. 2011, 2012, Liu et al. 2011) and a better understanding of Thailand's fungi. However, only a few published studies have established the diversity of fungal communities and overlapping fungi on litter types in the tropics (Yanna et al. 2001, Ananda \& Sridhar 2004, Paulus et al. 2006, Yule \& Gomez 2008). There are still many unidentified taxa which need to be discovered (Duong et al. 2004).

Magnolia liliifera (L.) Baill. (Magnoliaceae) is an evergreen tree and in northern Thailand, is commonly located in Doi Suthep-Pui National Park (Gardner et al. 2000). $M$. liliifera leaves are large and thick and this host is a good source for saprobic fungi (Promputtha et al. 2004). Promputtha et al. (2002, 2004) studied saprobic fungi on $M$. liliifera leaves in the forest of Doi Suthep-Pui National Park during the wet season of 2001. They found many diverse fungal communities and undescribed species (e.g. Anthostomella monthadoia, Dokmaia monthadangii, Hyponectria manglietiae, Pseudohalonectria suthepensis). Saprobic fungi on decaying woody litter of $M$. liliifera in the forest of Doi Suthep-Pui National Park during the wet and dry seasons were reported by Kodsueb et al. (2008). The results showed that samples collected in the dry season provided greater species richness than samples collected in the wet season.

Cinnamomum iners Reinw. ex Blume (Lauraceae) is an evergreen tree and has essential oils in the leaves, which are used for flavoring sweets and confectionery (Jantan et al. 1995). It has been reported that leaf extracts exhibit some biological and pharmaceutical activity (Jantan et al. 1992, Zaridah et al. 2006). In Thailand, there have been some studies concerning endophytic fungi from Cinnamomum species (Worapong et al. 2001, 2003, Lumyong et al. 2002, Suwannarach et al. 2010). Worapong et al. (2003) and Suwannarach et al. (2010) discovered new fungal species and strains that can produce volatile compounds. However, there has been no study on the fungal diversity on decaying $C$. iners leaves. It is therefore interesting to study these fungi to understand the relationship between fungi and host.

Most previous studies on saprobic fungi are based on the wet season when the number of fungi on the forest floor is abundant (Hyde et al. 2001, Parungao et al. 2002, Paulus et al. 2006). In this study we focused on saprobic fungi on Magnolia liliifera and Cinnamomum iners in the dry season at Doi Suthep-Pui, Chiang Mai, Thailand. The purposes of the present study were to examine fungal communities and compare fungal species between two hosts and to establish whether fungal saprobes are host-specific or hostrecurrent (Zhou \& Hyde 2001). In addition, the saprobic fungal communities on each host were evaluated for the effect of different stages of decomposition.

\section{Methods}

\section{Study site and sample collection}

The study site was located in an evergreen forest in Doi Suthep-Pui, Chiang Mai, northern Thailand (N 18 48' 18.73”, E 98 '54' 47.28", elev., $107 \mathrm{~m}$ ) and samples were collected in the dry season between November 2009 and April 2010, when there was low humidity; the forest floor was damp but not wet. Ten decaying leaves were randomly collected from each individual tree of Magnolia liliifera and Cinnamomum iners in $100 \mathrm{~m}^{2}$ plots and returned to the laboratory.

\section{Fungal examination and isolation}

Leaves were divided into two stages of decomposition (five leaves for each stage); stage I were recently green or yellow fallen leaves and stage II were mostly decaying brown leaves. Samples were incubated in 15 $\mathrm{cm}$ diameter sterile Petri dishes with a tissue paper moistened with sterile distilled water at room temperature (Manoch 2004). Leaves were examined for fungi over six weeks of incubation. Fungi were identified based on morphological characters using relevant references (e.g. Ellis 1971, 1976, Carmichael et al. 1980, Sutton 1980, Sivanesan 1984, Hanlin 1990, 1998a, 1998b, Nag Raj 1993, Seifert et al. 2011). Single spore isolation method was used in fungal isolation (Choi et al. 1999; 
Chomnunti et al. 2011). All cultures were grown on potato dextrose agar (PDA) and malt extract agar (MEA) and deposited in MFLU Culture Collection (MFLUCC) and BIOTEC Culture Collection (BCC).

\section{Data analysis}

The percentage occurrence of fungi was calculated and fungal taxa with a percentage occurrence higher than 10 are regarded as 'common species' in this study. The formula of fungal percentage occurrence was measured by using the following formula:

Percentage occurrence $=\frac{\begin{array}{l}\text { Number of leaves on which fungus } \\ \text { was detected }\end{array}}{\text { total number of leaves examined }} \times 100$

Species diversity were compared at each stage of decomposition (stage I and II) using diversity indices to demonstrate the result of species diversity of a community (Shannon $\&$ Weaver 1949). Species richness means the number of fungal species in a community and species evenness means the contribution (relative equability) of individuals (McCune \& Grace 2002). The Shannon index ( $\left.\mathrm{H}^{\prime}\right)$ refers to the abundance of species diversity of a community and the Shannon evenness (E') refers to the equability of species diversity, which ranges from 0 to 1 . If the Shannon evenness is equal to 1 , then every species in the community has the same frequency of occurrence. The Shannon index is calculated according to the equation:

$$
H^{\prime}=-\sum_{i=1}^{n} P_{i} \log _{e} P_{i}, \text { and } P_{i}=\frac{N_{i}}{N}
$$

Where, $N_{i}$ is individual number of $i$ species, $N$ is individual number of all species, $P_{i}$ is the proportion of $i$ species, $n$ is the number of species.

The Shannon evenness is calculated according to the equation:

\section{$\mathrm{E}^{\prime}=\mathrm{H} / \mathrm{lnS}$ (S: total species number).}

Sørensen's index of similarity was used to compare the similarity of the species on different hosts (Magurran 1988). Sørensen's similarity index $=2 \mathrm{c} / \mathrm{a}+\mathrm{b}$, where $\mathrm{a}=$ the number of species in host $A, b=$ the number of species in host $\mathrm{B}, \mathrm{c}=$ the number of species in common in both hosts. Similarity is expressed with values between 0 (no similarity) and 1 (absolute similarity).

The overlap of fungi from different hosts were calculated using the Sørensen quotient:

Overlap $(\%)=\frac{\text { number of taxa shared between host A and host B }}{\text { total number of taxa observed in host A and host B }} \times 100$

\section{Results and Discussion}

\section{Diversity of saprobic fungi on Magnolia liliifera and Cinnamomum iners}

In this study, fungal diversity on decaying leaves of $M$. liliifera and $C$. iners in the dry season in northern Thailand was investigated. A total of 139 fungal collections were made and 35 taxa were identified from decaying leaves of $M$. liliifera. This comprised 8 ascomycetes (representing 23\% of all taxa) and 27 anamorphic fungi $(77 \%)$ including 11 coelomycetes $(31 \%)$ and 16 hyphomycetes $(46 \%)$. The most abundant species were Sporidesmium sp. (80\%), Colletotrichum fructicola (70\%), Stachybotrys parvispora (70\%), Dicyma pulvinata (60\%), Lasiosphaeria-like sp. $1(60 \%)$ and Volutella consors (60\%).

In decaying leaves of $C$. iners, 58 fungal collections were made and 17 taxa were identified. This comprised two ascomycetes (representing $11 \%$ of all taxa) and 15 anamorphic fungi (89\%) including 6 coelomycetes (33\%) and 9 hyphomycetes $(56 \%)$. The most abundant species were anamorph of Eutypa sp. 2 (60\%), Pleurophragmium sp. (60\%), Acremonium sp. (40\%), Colletotrichum sp. (40\%) and Hyphomycetes sp. 2 (40\%). Percentage occurrence of fungi occurring on $M$. liliifera and $C$. iners are shown in Table 1. Diversity indices of fungi on decaying leaves of $M$. liliifera and $C$. iners are shown in Table 2.

Fungal diversity of $M$. liliifera in the dry season can be compared with previous studies in the wet season (Promputtha et al. 2002, 2004). Twenty-two taxa of fungi were recorded in a succession study was from 110 leaf samples (Promputtha et al. 2002). Thirty-seven taxa were recorded on naturally 
occurring decaying leaves from 90 leaf samples (Promputtha et al. 2004). In the present study, 35 fungal taxa were identified from 10 leaf samples. This sample number was shown to be a threshold for studying fungal diversity in $M$. liliifera (Promputtha et al. pers. obs.). It seems that leaves of $M$. liliifera in the dry season support more fungal taxa than in the wet season. Similar results were reported by Kodsueb et al. (2008) and Seephueak et al. (2010, 2011) who found that samples collected in the dry season had greater species richness and higher Shannon diversity index than samples collected in the wet season. There were no seasonal effects of fungal communities on palms in Hong Kong (Yanna et al. 2001) or on Pandanus penetrans in Thailand (Thongkantha et al. 2008). The reason is still unclear. Pinnoi et al. (2006) showed that the spore germination and reproduction of fungi required quite high humidity. Rayner \& Todd (1979) reported that the wettest period had an unsuitable ratio between moisture content and aeration of wood with relative high moisture and low aeration. Fungal composition and dominant species reported by Promputtha et al. (2002, 2004) were different from this study. Only a few overlapping genera occurred in both studies (Colletotrichum, Phaeosphaeria, Phomopsis, Stachybotrys and Volutella); S. parvispora is the only overlapping species between the two studies. Nevertheless, the given name of taxa may be different following sexual-asexual states which were present on samples. Clonostachys rosea was found in this study, whereas Bionectria ochroleuca, which is linked to sexual states of this fungus (Schroers 2001), was reported by Promputtha et al. (2002, 2004). However, differences in the number of samples and the years of collecting, which varied in temperature, humidity and rainfall make comparisons difficult.

Only 17 fungal taxa were identified from $C$. iners leaves and most were anamorphic fungi. Lumyong et al. (2000) isolated endophytic fungi from $C$. iners collected from Doi Suthep-Pui National Park, Thailand. The genera of endophytes (Lumyong et al. 2002) were not the same as in our study except for Colletotrichum sp. Fungal diversity on $M$. liliifera leaves provides greater species richness and Shannon diversity indices than fungi on $C$. iners leaves (see Table 2). A reason for this may be that leaves of $M$. liliifera are larger than those of $C$. iners. Larger leaves are likely to provide higher species diversity than smaller leaves (Wong \& Hyde 2001). This is consistent with previous studies on hosts such as banana, palm and $M$. liliifera, which supported higher diversity and more diverse taxa (Photita et al. 2001, 2003, Yanna et al. 2001, Promputtha et al. 2002, 2004). Chemical composition of leaves may affect fungal numbers. Leaves of $C$. iners contain essential oils such as eugenol and cinnamaldehyde as major bioactive compounds (Jantan et al. 1992). Reports have shown antimicrobial activities of essential oils from Cinnamomum species (Jantan et al. 1992, Ranasinghe et al. 2002, Mustaffa et al. 2011). Antifungal tests demonstrated that cinnamaldehyde and eugenol had strong inhibitory effect against wood decay fungi (Wang et al. 2005, Cheng et al. 2006), while Yen \& Chang (2008) concluded that the synergy of cinnamaldehyde with eugenol could alter cell wall structure of fungi, reduce cell wall synthesis, and the addition of radical scavenging. Such factors may lead to a reduced number of fungi on $C$. iners leaves.

\section{Host specificity}

Overlapping genera on both hosts were anamorph of Eutypa, Colletotrichum, Lasiodiplodia and Ophioceras. Only one species, Lasiodiplodia theobromae, overlapped on both hosts. Sørensen's similarity index, overlap (\%) of fungi from the two hosts are shown in Table 3. Few taxa overlapped between the two hosts, and this resulted in a low similarity index suggesting that saprobic fungi may be host-specific. Fungal composition between hosts in different families has been shown to be varied (Wang \& Hyde 2001) and $M$. liliifera and $C$. iners are in different families. Saprobic fungi were less specific at host species level (Wang et al. 2008). Other factors such as season, location and number of samples might also affect the host specific of saprobic fungi. Further studies in wet season with other hosts and/or other locations should be done to determine host-specificity of saprobic fungi. 


\section{Effect of decomposing stages on fungal communities}

The percentage occurrence of fungi on $M$. liliifera and $C$. iners at each stage of decomposition are given in Table 1. On $M$. liliifera dominant species at stage $\mathrm{I}$ of decomposition were Dicyma pulvinata (100\%), Sporidesmium sp. (100\%) and Volutella consors $(100 \%)$. The most abundant species at stage II of decomposition were anamorph of Eutypa sp. 1 (60\%), Colletotrichum fructicola (60\%), Sporidesmium (60\%), Ophioceras cf. leptosporum (60\%) and Stachybotrys parvispora $(60 \%)$. For $C$. iners, the most abundant species at stage I of decomposition were Acremonium sp. (60\%), Pleurophragmium sp. (60\%), anamorph of Eutypa sp. 2 (40\%), Coelomycete sp. 5 (40\%), Colletotri-chum sp. (40\%), Hyphomycete sp. 2 (40\%), Lasiodiplodia theobromae (40\%) and Pyricu-laria costina (40\%). The most abundant species in stage II of decomposition were anamorph of Eutypa sp. 2 (80\%), Pleurophragmium sp. (60\%), Colletotrichum sp. (40\%), Graphium sp. (40\%) and Hyphomycete sp. 2 (40\%).

Species richness, species evenness, Shannon indices $\left(\mathrm{H}^{\prime}\right)$ and Shannon evenness $\left(E^{\prime}\right)$ at each stage of decomposition of fungi on $M$. liliifera and $C$. iners were calculated (Table $2)$. On $M$. liliifera, the number of species at stage I of decomposition was higher than that at stage II of decomposition, but stage I of decomposition has a lower diversity of fungi than stage II of decomposition. On $C$. iners, leaves in stage I of decomposition supported a greater diversity of fungi than leaves in stage II and the number of species in stage I was higher than the number of species in stage II of decomposition.

The replacement of fungal species sequentially throughout the decomposing process relies on the capability of decomposers to utilize organic matter and nutrients, which are particular to each substrate or host (Frankland 1992, Tang et al. 2005). In the early stage, decomposer fungi might switch their roles from endophytes or pathogens (Lodge \&
Cantrell 1995, Duong et al. 2008). The evidence that endophytic fungi change to be saprobes has been reported in many previous studies (Osono et al. 2004, 2009, Koide et al. 2005, Tang et al. 2005, Promputtha et al. 2010, Purahong \& Hyde 2011). Promputtha et al. (2010) also showed that endophytes can produce various degrading enzymes in succession process, which is an important activity for their adaptation to a saprobic lifestyle. The primary enzymes degrade small soluble carbon-based molecules, such as hemicelluloses and the most complex cellulose and lignin are then degraded at the late stage of decomposition (McClaugherty \& Berg 1987, Promputtha et al. 2010). In addition, soilborne and airborne fungi can colonize fallen leaves (Duong et al. 2008) so that leaves which have been on the forest floor for a long time might have higher fungal diversity than leaves which have recently fallen. In this study, decaying leaves of $M$. liliifera and $C$. iners at stage I of decomposition supported a greater fungal diversity than in stage II of decomposition suggesting that endophytic fungi might play an important role in the decay of dead leaves and these fungi are different at different stages of decay. Shanthi \& Vitthal (2010) studied leaf litter fungi of Pavetta indica on freshly fallen senescent leaves and on leaves already undergoing active decomposition and found more taxa on the former than on the latter. Seephueak et al. $(2010,2011)$ studied fungi at different stages of decaying leaf and branch litter of the rubber tree. They showed that the number of taxa on middle stage decaying branches was higher than new and old decaying fallen branches.

The results presented here show that the fungi on the two plants are hyperdiverse and that there is very little overlap between the fungi occurring on the two host species. The data provides evidence to suggest that the number of fungal species worldwide (Hawksworth 1991, 2001) are at least at great as estimated (Hawksworth \& Rossman 1997, Hyde et al. 2007). 
Table 1 Percentage occurrence of fungi occurring on Magnolia liliifera and Cinnamomum iners at two stages of decomposition.

\begin{tabular}{|c|c|c|c|c|c|c|}
\hline \multirow{2}{*}{ Fungal species } & \multicolumn{3}{|c|}{ Magnolia liliifera } & \multicolumn{3}{|c|}{ Cinnamomum iners } \\
\hline & Stage I* & Stage II* & Overall & Stage I* & Stage II* & Overall \\
\hline Acremonium sp. & & & & 60 & 20 & 40 \\
\hline Anamorph of Eutypa sp. 1 & & 60 & 30 & & & \\
\hline Anamorph of Eutypa sp. 2 & & & & 40 & 80 & 60 \\
\hline Ascomycete sp. 1 & & 20 & 10 & & & \\
\hline Ascomycete sp. 2 & & 20 & 10 & & & \\
\hline Beltrania rhombica & 40 & & 20 & & & \\
\hline Botryosphaeria sp. & 20 & 20 & 20 & & & \\
\hline Canalisporium caribense & & 20 & 10 & & & \\
\hline Chaetomium sp. & & & & 20 & & 10 \\
\hline Cladosporium sp. 1 & 20 & & 10 & & & \\
\hline Cladosporium sp. 2 & & 20 & 10 & & & \\
\hline Clonostachys compactiuscula & 20 & & 10 & & & \\
\hline Clonostachys rogersoniana & 20 & & 10 & & & \\
\hline Clonostachys rosea & 20 & & 10 & & & \\
\hline Coelomycete sp. 1 & 20 & & 10 & & & \\
\hline Coelomycete sp. 2 & & 20 & 10 & & & \\
\hline Coelomycete sp. 3 & & 20 & 10 & & & \\
\hline Coelomycete sp. 4 & & & & 20 & & 10 \\
\hline Coelomycete sp. 5 & & & & 40 & & 20 \\
\hline Colletotrichum fructicola & 80 & 60 & 70 & & & \\
\hline Colletotrichum sp. & & & & 40 & 40 & 40 \\
\hline Dicyma pulvinata & 100 & 20 & 60 & & & \\
\hline Ellisiopsis occulta & & & & 20 & & 10 \\
\hline Fusicoccum aesculi & 40 & 20 & 30 & & & \\
\hline Gliocladium sp. & & & & 20 & & 10 \\
\hline Graphium penicillioides & & & & 20 & & 10 \\
\hline Graphium sp. & & & & & 40 & 20 \\
\hline Hyphomycete sp. 1 & 20 & & 10 & & & \\
\hline Hyphomycete sp. 2 & & & & 40 & 40 & 40 \\
\hline Hyphomycete sp. 3 & & & & & 20 & 10 \\
\hline Lasiodiplodia theobromae & 60 & & 30 & 40 & 20 & 30 \\
\hline Lasiosphaeria-like sp. & 80 & 40 & 60 & & & \\
\hline Montagnula sp. & & 40 & 20 & & & \\
\hline Nodulisporium sp. & & 20 & 10 & & & \\
\hline Ophioceras cf. commune & & & & & 20 & 10 \\
\hline Ophioceras cf. leptosporum & 20 & 60 & 40 & & & \\
\hline Pestalotiopsis sp. & 20 & & 10 & & & \\
\hline Phaeosphaeria sp. & 40 & & 20 & & & \\
\hline Phialophora sp. & & 20 & 10 & & & \\
\hline Phoma sp. 1 & 60 & 40 & 50 & & & \\
\hline Phoma sp. 2 & 20 & & 10 & & & \\
\hline Phomatospora sp. & 20 & & 10 & & & \\
\hline Phomopsis sp. & 20 & & 10 & & & \\
\hline Pleurophragmium sp. & & & & 60 & 60 & 60 \\
\hline Pyrenochaeta sp. & & & & 20 & & 10 \\
\hline Pyricularia costina & & & & 40 & & 20 \\
\hline Sporidesmium sp. & 100 & 60 & 80 & & & \\
\hline Stachybotrys parvispora & 80 & 60 & 70 & & & \\
\hline Stachylidium bicolor & & 20 & 10 & & & \\
\hline Volutella consors & 100 & 20 & 60 & & & \\
\hline Zygosporium sp. & & 20 & 10 & & & \\
\hline
\end{tabular}

*Stage I = Stage I of decomposition, -Stage II = Stage II of decomposition 
Table 2 Diversity indices of fungi from Magnolia liliifera and Cinnamomum iners at two stages of decomposition.

\begin{tabular}{lcccc}
\hline & \multicolumn{2}{c}{ Magnolia liliifera } & \multicolumn{2}{c}{ Cinnamomum iners } \\
& Stage I- & Stage II* & Stage I* & Stage II*- \\
\hline Species richness & 23 & 21 & 14 & 9 \\
Species evenness & 88 & 44 & 24 & 17 \\
Shannon indices & 2.84 & 2.9 & 2.56 & 2.1 \\
Shannon evenness & 0.74 & 0.84 & 0.92 & 0.9 \\
\hline
\end{tabular}

*Stage I = Stage I of decomposition, Stage II of decomposition

Table 3. Sørensen's similarity index and, overlap (\%) of fungi from Magnolia liliifera and Cinnamomum iners.

\begin{tabular}{lll}
\hline & Overlapping genera & Overlapping species \\
\hline Sørensen's similarity index & 0.17 & 0.04 \\
Overlap $(\%)$ & 8.51 & 1.92 \\
\hline
\end{tabular}

\section{Acknowledgements}

This work was supported by The Thailand Research Fund BRG5280002. The authors thank Scientific and Technological Instruments Center, Mae Fah Luang University for providing facilities. Appreciation is extended to Prof. D.J. Bhat for helping with identification of fungi.

\section{References}

Ananda K, Sridhar KR. 2004 - Diversity of filamentous fungi on decomposing leaf and woody litter of mangrove forests in the southwest coast of India. Current Science 87(10), 1431-1437.

Bhilabutra W, McKenzie EHC, Hyde KD, Lumyong S. 2010 - Fungi on the grasses, Thysanolaena latifolia and Saccharum spontaneum, in northern Thailand. Mycosphere 1(4), 301-314.

Boonmee S, Zhang Y, Chomnunti P, Chukeatirote E, Tsui CKM, Bahkali AH, Hyde KD. 2011 - Revision of lignicolous Tubeufiaceae based on morphological reexamination and phylogenetic analysis. Fungal Diversity 51, 63-102.

Boonmee S, Ko Ko TW, Chukeatirote E, Hyde KD, Chen H, Cai L, McKenzie EHC, Jones EBG, Kodsueb R, Bahkali AH. 2012 - Two new Kirschsteiniothelia species with a Dendryphiopsis anamorph cluster in Kirschsteiniotheliaceae fam. nov. Mycologia 104(3), 698-714.

Carmichael JW, Kendrick WB, Conners IL, Sigler L. 1980 - Genera of Hyphomycetes. University of Alberta Press, Edmonton.

Cheng SS, Liu JY, Hsui YR, Chang ST. 2006 Chemical polymorphism and antifungal activity of essential oils from leaves of different provenances of indigenous cinnamon (Cinnamomum osmophloeum). Bioresource Technology 97, 306312.

Choi YW, Hyde KD, Ho WH. 1999 - Single spore isolation of fungi. Fungal Diversity 3, 29-38.

Chomnunti P, Schoch CL, Aguirre-Hudson B, Ko-Ko TW, Hongsanan S, Jones EBG, Kodsueb R, Phookamsak R, Chukeatirote E, Bahkali AH, Hyde KD. 2011 - Capnodiaceae. Fungal Diversity 51, 103-134.

Cooke RC, Rayner ADM. 1984 - Ecology of Saprotrophic Fungi. Longman, London.

Duong ML, Lumyong S, Hyde KD. 2004 Fungi on leaf litter. In: Thai Fungal Diversity (eds EBG Jones, M Tantichareon, KD Hyde). BIOTEC, Bangkok, 163-171.

Duong ML, McKenzie EHC, Lumyong S, Hyde KD. 2008 - Fungal succession on senescent leaves of Castanopsis diversifolia in Doi Suthep-Pui National 
Park, Thailand. Fungal Diversity 30, 2336.

Ellis MB. 1971 - Dematiaceous Hyphomycetes. Commonwealth Mycological Institute, Surrey.

Ellis MB. 1976 - More Dematiaceous Hyphomycetes. Commonwealth Mycological Institute, Surrey.

Fournier J, Stadler M, Hyde KD, Duong ML. 2010 - The new genus Rostrohypoxylon and two new Annulohypoxylon species from Northern Thailand. Fungal Diversity 40, 23-36.

Frankland JE. 1992 - Mechanisms in fungal succession. In: The Fungal Community (eds DT Wicklow, GC Carroll), 2nd edn. Marcel Dekker, New York.

Gardner S, Sidisunthorn P, Anusarnsunthorn V. 2000 - A Field Guide To Forest Trees of Northern Thailand. Kobfai Publishing Project, Bangkok.

Hanlin RT. 1990 - Illustrated Genera of Ascomycetes. American Phytopathological Society, Minnesota.

Hanlin RT. 1998a - Combined Keys to Illustrated Genera of Ascomycetes, Volumes I \& II. American Phytopathological Society, Minnesota.

Hanlin RT. 1998b - Illustrated Genera of Ascomycetes, Volume II. American Phytopathological Society, Minnesota.

Hawksworth DL. 1991 - The fungal dimension of biodiversity: magnitude, significance, and conservation. Mycological Research 95, 641-655.

Hawksworth DL. 2001 - The magnitude of fungal diversity: the 1.5 million species estimate revisited. Mycological Research 105(12), 1422-1432.

Hawksworth DL, Rossman AY. 1997 - Where are all the undescribed fungi. Phytopathology 87, 888-891.

Hyde KD. 2001 - Where are the missing fungi? Does Hong Kong have any answers? Mycological Research 105(12), 15141518.

Hyde KD, Bussaban B, Paulus B, Crous PW, Lee S, McKenzie EHC, Photita W, Lumyong S. 2007 - Diversity of saprobic microfungi. Biodiversity and Conservation 16(1), 7-35.

Jantan I, Mat AR, Hock GS. 1992 - Toxic and antifungal properties of the essential oils of Cinnamomum species from Peninsular Malysia. Journal of Tropical Forest Science 6(3), 286-292.

Jantan I, Wiselius SI, Lim SC, Sosef MSM. 1995 - Cinnamomum Schaeffer. In: Plant Resources of South-East Asia No.5(2) Timber Trees: Minor Commercial Timbers (eds RHMJ Lemmens, I Soerianegara, WC Wong). Prosea Foundation, Bogor, 130-140.

Kodsueb R, McKenzie EHC, Lumyong S, Hyde KD. 2008 - Diversity of saprobic fungi on Magnoliaceae. Fungal Diversity 30, 37-53.

Koide K, Osono T, Takeda H. 2005 - Fungal succession and decomposition of Camellia japonica leaf litter. Ecological Research 20, 599-609.

Liu JK, Phookamsak R, Jones EBG, Zhang Y, Ko-Ko TW, Hu HL, Boonmee S, Doilom M, Chukeatirote E, Bahkali AH, Wang Y, Hyde KD. 2011 Astrosphaeriella is polyphyletic, with species in Fissuroma gen. nov., and Neoastrosphaeriella gen. nov. Fungal Diversity 51, 135-154.

Lodge DJ, Cantrell S. 1995 - Fungal communities in wet tropical forest variation in time and space. Canadian Journal of Botany 73(Suppl. 1), S1391S1398.

Lumyong S, Lumyong P, McKenzie EHC, Hyde KD. 2002 - Enzymatic activity of endophytic fungi of six native seedling species from Doi Suthep-Pui National Park, Thailand. Canadian Journal of Microbiology 48(12), 1109-1112.

Magurran AE. 1988 - Ecological Diversity and its Measurement. Croom Helm, London.

Manoch L. 2004 - Some noteworthy microfungi from soil, dung and plant; 1st KMITL International Conference on Integration of Science and Technology for Sustainable Development. Bangkok, Thailand, August 25-26, 42-47.

McClaugherty CA, Berg B. 1987 - Cellulose, lignin and nitrogen concentrations as rate regulating factors in late stages of forest litter decomposition. Pedobiologia 30, 101-112.

McCune B, Grace JB. 2002 - Analysis of 
Ecological Communities. MjM Software Design, Oregon.

Mustaffa F, Indurkar J, Ismail S, Shah M, Mansor SM. 2011. An antimicrobial compound isolated from Cinnamomum iners leaves with activity against methicillin-resistant Staphylococcus aureus. Molecules 16(4), 3037-3047.

Nag Raj TR. 1993 - Coelomycetous Anamorphs with Appendage-Bearing Conidia. Mycologue Publications, Ontario.

Osono T, Bhatta BK, Takeda H. 2004 Phyllosphere fungi on living and decomposing leaves of giant dogwood. Mycoscience 45, 35-41.

Osono T, Ishii Y, Takeda H, Seramethakun T, Khamyong S, To-Anun C, Hirose D, Tokumasu S, Kakishima M. 2009 Fungal succession and lignin decomposition on Shorea obtusa leaves in a tropical seasonal forest in northern Thailand. Fungal Diversity 36, 101-119.

Parungao MM, Fryar SC, Hyde KD. 2002 Diversity of fungi on rainforest litter in North Queensland, Australia. Biodiversity and Conservation 11, 11851194.

Paulus BC, Kanowski J, Gadek PA, Hyde KD. 2006 - Diversity and distribution of saprobic microfungi in leaf litter of an Australian tropical rainforest. Mycological Research 110(12), 14411454.

Photita W, Lumyong S, Lumyong P, Ho WH, McKenzie EHC, Hyde KD. 2001 Fungi on Musa acuminata in Hong Kong. Fungal Diversity 6, 99-106.

Photita W, Lumyong P, McKenzie EHC, Hyde KD, Lumyong S. 2003 - Saprobic fungi on dead wild banana. Mycotaxon 80, 345-356.

Pinnoi A, Lumyong S, Hyde KD, Jones EBG. 2006 - Biodiversity of fungi on the palm Eleiodoxa conferta in Sirindhorn peat swamp forest, Narathiwat, Thailand. Fungal Diversity 22, 205-218.

Promputtha I, Lumyong S, Lumyong P, McKenzie EHC, Hyde KD. 2002 Fungal succession on senescent leaves of Manglietia garrettii in Doi Suthep-Pui National Park, northern Thailand. Fungal Diversity 10, 89-100.
Promputtha I, Lumyong S, Lumyong P, McKenzie EHC, Hyde KD. 2004 Fungal saprobes on dead leaves of Magnolia lillifera (Magnoliaceae) in Thailand. Cryptogamie Mycologie 25, 43-47.

Promputtha I, Hyde KD, McKenzie EHC, Peberdy JF, Lumyong S. 2010 - Can leaf degrading enzymes provide evidence that endophytic fungi becoming saprobes? Fungal Diversity 41, 89-99.

Purahong W, Hyde KD. 2011 - Effects of fungal endophytes on grass and nongrass litter decomposition rates. Fungal Diversity 47, 1-7.

Ranasinghe L, Jayawardena B, Abeywickrama K. 2002 - Fungicidal activity of essential oils of Cinnamomum zeylanicum (L.) and Syzygium aromaticum (L.) Merr et L.M. Perry against crown rot and anthracnose pathogens isolated from banana. Letters in Applied Microbiology 35, 208-211.

Rayner ADM, Todd NK. 1979 - Population and community structure and dynamics of fungi in decaying wood. Advances in Botanical Research 7, 333-420.

Schroers HJ. 2001 - A monograph of Bionectria (Ascomycota, Hypocreales, Bionectriaceae) and its Clonostachys anamorphs. Studies in Mycology 46, $73-$ 74.

Seephueak P, Petcharat P, Phongpaichit S. 2010 - Fungi associated with degrading leaf litter of para rubber (Hevea brasiliensis). Mycology 1(4), 213-227.

Seephueak P, Phongpaichit S, Hyde KD, Petcharat V. 2011 - Diversity of saprobic fungi on decaying branch litter of the rubber tree (Hevea brasiliensis). Mycosphere 2(4), 307-330.

Seifert K, Morgan-Jones G, Gams W, Kendrick B. 2011 - The Genera of Hyphomycetes. CBS-KNAW Fungal Biodiversity Centre, Utrecht.

Shannon CE, Weaver W. 1949 - The Mathematical Theory of Communication. University of Illinois Press, Urbana.

Shanthi S, Vittal BPR. 2010 - Biodiversity of microfungi associated with litter of 
Pavetta indica. Mycosphere 1, 23-37.

Sivanesan A. 1984 - The Bitunicate Ascomycetes and their Anamorphs. J. Cramer, Vaduz.

Sutton BC. $1980-$ The Coelomycetes. Commonwealth Mycological Institute, Surrey.

Suwannarach N, Bussaban B, Hyde KD, Lumyong S. 2010 - Muscodor cinnamomi, a new endophytic species from Cinnamomum bejolghota. Mycotaxon 114, 15-23.

Sysouphanthong P, Thongkantha S, Zhao R, Soytong K, Hyde KD. 2010 Mushroom diversity in sustainable shade tea forest and the effect of fire damage. Biodiversity and Conservation 19, 14011415.

Tang AMC, Jeewon R, Hyde KD. 2005 Succession of microfungal communities on decaying leaves of Castanopsis fissa. Canadian Journal of Botany 51, 967974.

Thongkantha S, Lumyong S, McKenzie EHC, Hyde KD, 2008 - Fungal saprobes and pathogens occurring on tissues of Dracaena lourieri and Pandanus spp. in Thailand. Fungal Diversity 30, 149-169.

Vasilyeva LN, Stephenson SL, Hyde KD, Bahkali AH. 2012 - Some stromatic pyrenomycetous fungi from northern Thailand - 1. Biscogniuxia, Camillea and Hypoxylon (Xylariaceae). Fungal Diversity 55, 65-76.

Wang HK, Hyde KD, Soytong K, Lin FC. 2008 - Fungal diversity on fallen leaves of Ficus in northern Thailand. Journal of Zhejiang University SCIENCE B 9(10), 835-841.

Wang SY, Chen PF, Chang ST. 2005 Antifungal activities of essential oils and their constituents from indigenous cinnamon (Cinnamomum osmophloeum) leaves against wood decay fungi. Bioresource Technology 96, 813-818.

Wong MKM, Hyde KD. 2001 - Diversity of fungi on six species of Gramineae and one species of Cyperaceae in Hong Kong. Mycological Research 105(12), 1485-1491.

Worapong J, Strobel G, Ford EJ, Li JY, Baird G, Hess WM. 2001 - Muscodor albus anam. gen. et sp. nov., an endophyte from Cinnamomum zeylanicum. Mycotaxon 79, 67-79.

Worapong J, Inthararaungsom S, Strobel G, Hess WM. 2003 - A new record of Pestalotiopsis theae, existing as an endophyte on Cinnamomum iners in Thailand Mycotaxon 88, 365-372.

Yanna, Ho WH, Hyde KD. 2001 - Fungal communities on decaying palm fronds in Australia, Brunei, and Hong Kong. Mycological Research 105 (12), 14581471.

Yen TB, Chang ST. 2008 - Synergistic effects of cinnamaldehyde in combination with eugenol against wood decay fungi. Bioresource Technology 99, 232-236.

Yule CM, Gomez LN. 2009 - Leaf litter decomposition in a tropical peat swamp forest in Peninsular Malaysia. Wetlands Ecology and Management 17, 231-241.

Zaridah MZ, Nor Azah MA, Rohani A. 2006 Mosquitocidal activities of Malaysian plants. Journal of Tropical Forest Science 18(1), 74-80.

Zhao R, Desjardin DE, Soytong K, Perry AB, Hyde KD. 2010 - A monograph of Micropsalliota in Northern Thailand based on morphological and molecular data. Fungal Diversity 45, 33-79.

Zhou D, Hyde KD. 2001 - Host-specificity, host-exclusivity, and host-recurrence in saprobic fungi. Mycological Research 105(12), 1449-1457. 